ECOLOGICA, Vol. 28, No 104 (2021), 517-526

https://doi.org/10.18485/ecologica.2021.28.104.5

Originalni naučni rad

UDC: 628.3:549.67(497.11)

\title{
Potential of using domestic zeolite in water treatment systems in Serbia
}

\section{Potencijal upotrebe domaćeg zeolita u sistemima za tretman vode u Srbiji}

\section{Luka Latinović}

The School of Engineering Management, University Union - Nikola Tesla, Belgrade, Serbia Fakultet za inženjerski menadžment, Univerzitet Union - Nikola Tesla, Beograd, Srbija orcid.org/0000-0002-9324-667X

e-mail: luka.latinovic@fim.rs

Received: 14.10.2021, Accepted: 03.11.2021.

\begin{abstract}
Water as vital and undoubtedly the most important resource in the world is under tremendous pressure. Water scarcity has become a growing problem in many parts of the world and in the near future Serbia would be no exemption. It is a country with an extremely large gray water footprint in relation to GDP. This is largely due to the small number of wastewater treatment systems and the poor condition of existing ones as well as due to the inefficient control and fining of pollution generators. Mitigating unfavorable trends in pollution by hazardous metals and metalloids as well as in presence of ammonium in surface waters in Serbia is of great importance. Given the rich deposits of zeolite in the country, more precisely clinoptilolite, this paper discusses its potential for use in wastewater treatment systems in Serbia. Domestic clinoptilolite has proven to be efficient, of high quality and easily accessible, but the legislation and accompanying industrial infrastructure that would enable its exploitation are still not sufficiently developed.
\end{abstract}

Keywords: zeolite; clinoptilolite; pollution; wastewater; water treatment in Serbia.

Sažetak: Voda kao vitalan i nesumnjivo najvažniji resurs na svetu pod ogromnim je pritiskom. Nestašica vode postaje je rastući problem u mnogim delovima sveta i u bliskoj budućnosti Srbija neće biti izuzetak. To je zemlja sa izuzetno velikim otiskom sive vode u odnosu na BDP. Razlog tome su uglavnom nedovoljan broj sistema za prečišćavanje otpadnih voda i loše stanje postojećih, kao neefikasna kontrola i kažnjavanje zagađivača. Ublažavanje nepovoljnih trendova zagađenja hazardnim metalima i metaloidima, kao i prisustvo amonijuma u površinskim vodama u Srbiji je od velike važnosti. S obzirom na bogata nalazišta zeolita u zemlji, tačnije klinoptilolita, ovaj rad diskutuje njegov potencijal za primenu u sistemima za prečišćavanje otpadnih voda u Srbiji. Domaći klinoptilolit se pokazao efikasnim, visokokvalitetnim i lako dostupnim, ali zakoni i prateća industrijska infrastruktura koji bi omogućili njegovu eksploataciju još uvek nisu dovoljno razvijeni.

Ključne reči: zeolit; klinoptilolit; zagađenje; otpadna voda; tretman vode u Srbiji. 


\section{INTRODUCTION}

In nature, water circulates and constantly undergoes cycles of exploitation. Although it is regarded as a "renewable source", water pollution is a major concern. Groundwater e.g., globally the most important source of drinkable water, is mostly polluted by agricultural activities, which involve the use of artificial fertilizers. As for other industries and households' activities, variety of pollutants are being discharged either directly in surface waters or indirectly through atmosphere or septic tanks. Preserving the remaining clean water and reducing pollution in the process of its exploitation are the main goals in this century. The aim of this paper is to join that struggle and contribute to those goals, at least to some extent. Nevertheless, each country has specific problems as well as different resources and opportunities, thus can approach this problem in a different way. Water pollution is an extremely complex problem, the description of which requires the inclusion of a large number of scientific fields. However, given the upward trend in hazardous metals and metalloids and ammonium presence in surface waters in Serbia, the emphasis of this paper is on their removal. At the same time, Serbia is a country rich in deposits of clinoptilolite, an environmentally safe, low-cost natural zeolite that has the potential to remove numerous harmful cations and other harmful substances from water. It is present in several sedimentary deposits in Serbia and as such could be economically viable for use in water treatment systems. This paper further presents structural properties of natural zeolites, their potential in adsorption / ion exchange processes and examines the possibility and viability of their exploitation and application in water treatment systems.

\section{WATER QUALITY, POLLUTION AND MONITORING IN THE REPUBLIC OF SERBIA}

Just as it cannot avoid the trend of pollution by various globally present pollutants such as plastic (Latinović, 2018), Serbia unfortunately does not resist the pollution of water resources, either. Agency in charge of water quality monitoring is Serbian Environmental Protection Agency (SEPA), under the Ministry for Environmental protection of the Government of the Republic of Serbia. Analyzing 25,204 samples from 248 measuring points sampled on average once a month in the period 1998-2017, SEPA found the worst situation to be on the territory of Autonomous province Vojvodina. The quality indicator "poor" and "very poor" includes $40 \%$ of samples from this territory and only the class "very poor" as many as $79 \%$ of samples (SEPA, 2019), while other territories were also not without pollution. In 2017 , only $12.1 \%$ of municipal wastewater in Serbia has been treated prior its discharge to natural water recipients (SEPA, 2019). This is the highest amount of treated wastewater in 10 consecutive years. $87.9 \%$ polluted wastewater went to recipients untreated, which, according to SEPA (2019), amounted to $381,600,000 \mathrm{~m}^{3}$. Most untreated wastewater $(95 \%-100 \%)$ is in Nišava, Belgrade, Zlatibor, Bor, Rasina, Pirot, Braničevo and Srem areas. The least of them are in the Danube $(22.1 \%)$, Šumadija (30.8\%), North Banat (33.8\%) North Bačka (37.7\%), and Kolubara (45.9\%) areas (SEPA, 2019). However, the increase in the share of treated wastewater prior to discharge should be seen as a favorable trend. Considering the process of European integration of the Republic of Serbia (Jovanović et al., 2013; Jovanović et al., 2013a), it is expected that steps in this field at the state level will be taken to bring Serbia closer to European practices. However, this does not solve the global cost-effectiveness problem of the existing wastewater treatment practices, and technical solutions in this field does not include Serbian domestic potentials such as zeolite deposits. Furthermore, an unfavorable (growing) trend of average values of ammonium in the period 2008-2017 was determined at $26 \%$ of measuring points in the Republic of Serbia, while in the Sava basin, it was determined to be unfavorable (growing) trend at $86 \%$ (six out of seven) measuring points (SEPA, 2019).

However, as SEPA report stated, it is good that ammonium concentrations in the Sava River Basin are still relatively low. Still, in $2017,50 \%$ of measuring points had an average ammonium concentration higher than $0.1 \mathrm{mg} / \mathrm{l}$. Summarized data on the balance of emissions of hazardous metals, metalloids and their compounds in wastewater for 2018 are presented in the Fig. 1. In order to gain insight into the magnitude of the problem, zinc emissions in wastewater in 2015 were $25.8 \mathrm{t}$, compared to $109 \mathrm{t}$ in 2018 (SEPA, 2019). Although zinc is important for human health and has a variety of applications in the prevention of some diseases (Jovanović \& Ermakov, 2020), such amounts in rivers can disrupt a finely balanced ecosystem. Global environmental quality problems are always present in the economic development (Turanjanin et al., 2020), however, one of the main reasons that have led to this situation is the fact that the existing system of punishing polluters is very inefficient (Damnjanović, 2020). 


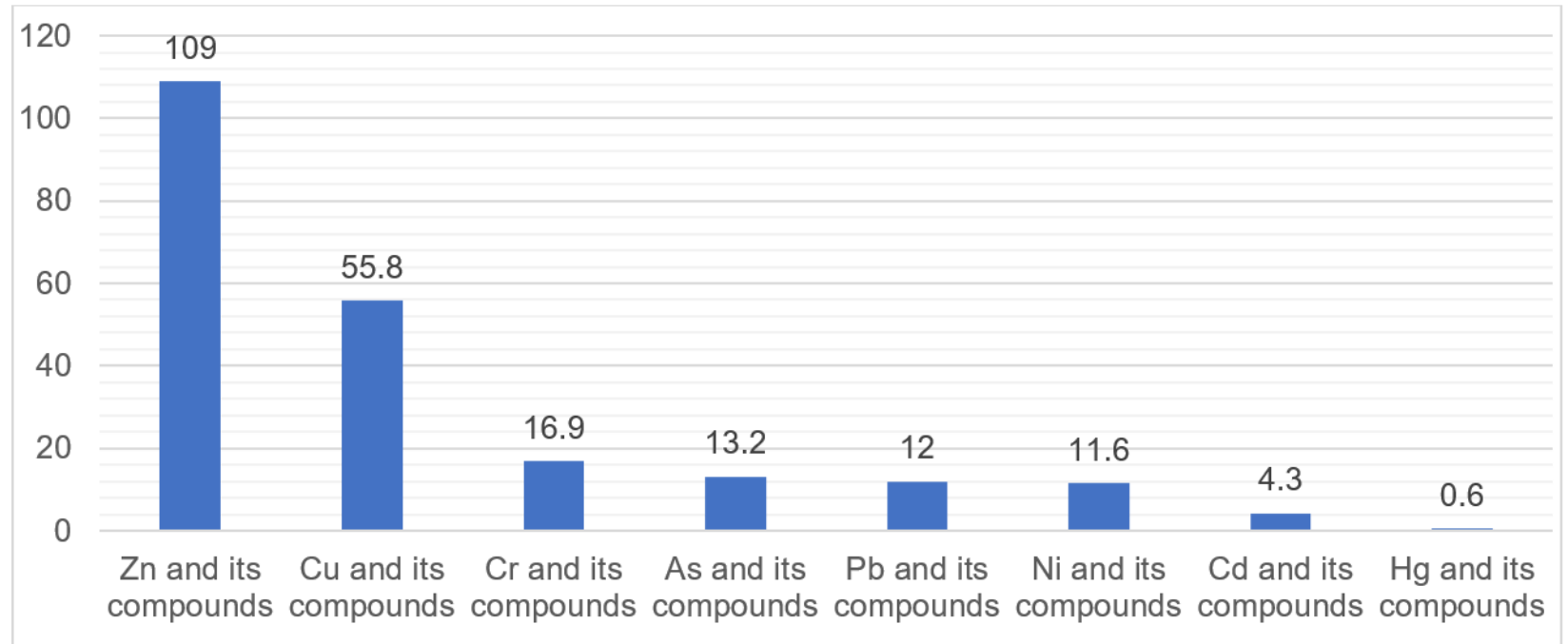

Figure 1. Emitted quantities of hazardous metals, metalloids and their compounds in wastewater, in tons, in the Republic of Serbia for year 2018 (SEPA, 2019).

\section{ZEOLITES, ADSORPTION AND ION- EXCHANGE PROCESSES IN WATER TREATMENT}

Zeolites are crystalline, microporous, hydrated aluminosilicates that are built from an infinitely extending three-dimensional network of $\left[\mathrm{SiO}_{4}\right]^{4-}$ and $\left[\mathrm{AlO}_{4}\right]^{5-}$ tetrahedra linked to each other by the sharing of oxygen atoms (Bekkum et al., 1991). Thanks to their unique structure, many zeolites, as well as clinoptilolite, are being used in various technological processes such as separation, adsorption, ion exchange and catalysis (Jovanović, 2016). Adsorption methods proved to be effective, economically efficient, easy to perform and construct (Margeta et al., 2013). Doula (2009) found out and concluded that on account of the excellent results of adsorption experiments in simultaneous removal of $\mathrm{Cu}, \mathrm{Mn}$ and $\mathrm{Zn}$ from drinking water, especially for the modified forms along with the fact that the clinoptilolite-Fe system is inexpensive, easily synthesized and regenerated, harmless for human beings, as well as for the environment, it can be considered as a very promising selective metal adsorbent (Doula, 2009). Other studies have also examined the potential of clinoptilolite in removing various other cations from water. In one study, the removal of arsenic from drinking water was examined by using modified adsorbents (natural zeolite) prepared by the use of different iron solutions. The arsenic sorption on the Fe-exchanged zeolite has been found to be able to reach up to $100 \mathrm{mg} / \mathrm{kg}$ (Li et al., 2011). In other studies, the use of natural and modified zeolites has been further investigated for the simultaneous removal of $\mathrm{Fe}$ and $\mathrm{Mn}$ ions from underground water samples (Inglezakis et al., 2010) and from artesian water (Tarasevich et al., 2012). Fe and Mn removal levels were found out to be between $22-90 \%$ and 61 $100 \%$ for natural zeolite - clinoptilolite (Tarasevich et al., 2012) and authors showed that with using the modified clinoptilolite it is possible to ensure stable de-manganation and de-ironing during a long period of time. Moreover, all studies showed that clinoptilolite had great potential in removing ammonium ions from water and that $\mathrm{NH}_{4}{ }^{+}$were most efficiently removed using clinoptilolite in Na-form whose selectivity in this multicomponent system was highest for $\mathrm{NH}_{4}{ }^{+}$ions (Du et al., 2005). All this goes in favor of zeolite clinoptilolite as a potential candidate for water purification in Serbia. However, in a study on the removal of ammonium from water solution with natural Turkish clinoptilolite, clinoptilolite was found out to be efficient, but with lower temperatures of the solution going in the favor of the ammonium uptake on it. This was found out to be due to exothermic nature of ammonium exchange process (Karadag et al., 2006). At the same time, at the ambient temperature, the Serbian natural zeolite was found out only to be moderately effective in removing the nickel(II) ions from aqueous solutions by adsorption (Rajić et al., 2010). Still, by increasing the temperature from $298^{\circ}$ to $338^{\circ} \mathrm{K}$, these authors found out a three-fold increase in the removal capacity. The $\mathrm{Ni}(\mathrm{II})$ ions were almost uniformly distributed inside the clinoptilolite adsorbent indicating that the removal of $\mathrm{Ni}(\mathrm{II})$ from water solution was mainly an ion-exchange. It was also found that the zeolite clinoptilolite shows selectivity alignments in ion exchange and affinity towards different cation given as $\mathrm{Ba}^{2+}>\mathrm{Cu}^{2+}, \mathrm{Zn}^{2+}>$ $\mathrm{Cd}^{2+}, \mathrm{Sr}^{2+}>\mathrm{Co}^{2+}$ (Blanchard et al., 1984), as $\mathrm{Pb}^{2+}>$ $\mathrm{Cd}^{2+}>\mathrm{Cs}^{+}>\mathrm{Cu} 2+>\mathrm{Co}^{2+}>\mathrm{Cr}^{3+}>\mathrm{Zn}^{2+}>\mathrm{Ni}^{2+}>\mathrm{Hg}^{2+}$ (Zamzow et al., 1990), or as $\mathrm{Co}^{2+}>\mathrm{Cu}^{2+}>\mathrm{Zn}^{2+}>$ $\mathrm{Mn}^{2+}$ (Erdem et al., 2004). This effect should be 
further examined because "Nickel dissolved" e.g., is one of the main priority hazardous substances whose maximum permitted concentrations exceeded limits at more than 20 measuring points in Serbia (SEPA, 2019). These findings impose custom and tailored approach in projecting a potential clinoptilolite based water treatment plant, based on spatial distribution of pollutants in surface water. Finally, Margeta, Zabukovec, Siljeg and Farkas, based on other numerous researches, gave an overview on efficiency of clinoptilolite in removal of different cations by adsorption / ion-exchange, as given in the Table 1.

Table 1. The efficiency of adsorption / ion-exchange removal of different cations by natural clinoptilolite (CLI) and modified clinoptilolite (M-CLI) (Margeta et al., 2013).

\begin{tabular}{|c|c|c|c|c|c|c|c|c|c|}
\hline & \multicolumn{10}{|c|}{ Removal efficiency, \% } \\
\cline { 2 - 11 } & $\mathrm{Cd}(\mathrm{II})$ & $\mathrm{Cr}(\mathrm{III})$ & $\mathrm{Cu}(\mathrm{II})$ & $\mathrm{Ni}(\mathrm{II})$ & $\mathrm{Zn}(\mathrm{II})$ & $\mathrm{Fe}(\mathrm{III})$ & $\mathrm{Mn}(\mathrm{II})$ & $\mathrm{Pb}(\mathrm{II})$ & $\mathrm{As}(\mathrm{III})$ \\
\hline CLI & 90 & 90 & 90 & 75 & 85 & 70 & - & 95 & - \\
\hline $\boldsymbol{M}$-CLI & $90-99$ & 88 & 80 & 37 & 92 & 90 & 70 & $90-99$ & 90 \\
\hline
\end{tabular}

Nevertheless, it should be noted that important factor of ensuring minimal cost of the sorbent is through its regeneration and reuse, eliminating the need to use new sorbent for every adsorption cycle and also ensuring the recovery of values. However, acidic and alkaline media and inorganic salts have been used as eluents for the regeneration of zeolites not always with success (Fosso-Kankeu et al., 2013). These authors provided several references in which researchers have claimed that acidic eluents were responsible for the degradation of zeolite and therefore reduced zeolite adsorption capacity, while alkaline conditions were reported not to be effective in most cases (Gedik \& Imamoglu, 2008; Gorimbo, 2011). Gorimbo (2011) reported dealumination and reduction of adsorption capacity of clinoptilolite due to the exposure to high concentration of acids. Conversely, exposure to base resulted in formation of internal precipitates and clogging of the pores in the zeolite framework. Although, this would probably not be the primary problem in Serbia, where zeolite is widely available with relatively low exploitation costs, efficient use and reuse keep pace with good practice in any technological advancement and is in line with the principles of circular economy (Ilić \& Nikolić, 2016), sustainable development (Garaplija, 2020; Latinović \& Jovanović, 2019) and "green economy" (Korać et al., 2019).

\section{TECHNOLOGICAL APPLICATION OF NATURAL ZEOLITES IN WATER TREATMENT}

Margeta, Zabukovec, Siljeg and Farkas (2013) presented numerous studies on application of natural zeolites in water treatment and stated that the excellent research results in the last 10 years have shown that natural zeolites have practical use. As they stated, this is also confirmed by a large number of patents, especially for the two naturally occurring zeolite minerals: clinoptilolite and mordenite. They further stated that the number of patents is substantial for both zeolite types, which gave these authors a clear notice that the interest of researcher in natural zeolites was strongly encouraged by the commercial sector covering the use in households or in industrial / large-scale processes and treatments. In neighboring Croatia, a pilot plant was constructed and put into operation to examine the removal of ammonium from the Valpovo region ground water (VGW) with the use of natural clinoptilolite samples from the Donje Jesenje deposit (Croatia) and the Zlatokop deposit in Vranjska Banja (Serbia) (Šiljeg et al., 2010). The natural Serbian (SZ) and Croatian zeolites (CZ) were transformed to the Na-form (Na-CZ and $\mathrm{Na}-\mathrm{SZ}$ ) in order to increase the exchange capacity of zeolite. The four "filter guard" vessels filled with zeolite samples were set in parallel in the ground water purification pilot plant (Fig. 2). The complete ammonium removal, with the use of SZ and $\mathrm{Na}-\mathrm{SZ}$ was achieved during $20 \mathrm{~h}$. After having observed saturation of clinoptilolite, they regenerated the samples with the use of 2 $\mathrm{mol} / \mathrm{dm}^{3} \mathrm{NaCl}$, and reused it for determination of ammonium sorption efficiency. The regenerated samples showed to be still very efficient for $\mathrm{NH}_{4}{ }^{+}$removal and, in addition, the SZ was shown as superior for ammonium removal in comparison to the CZ (Šiljeg et al., 2010). Still, if such filtration is to be used for wastewater treatment, instead for water drinking production plant, as is in this case, pre-filtration would be necessary to remove substances that would cause premature congestion of zeolite adsorbents. Finally, two standard procedures are usually applied to remove contaminants from water using zeolites: batch or continuous column procedures. Also, before practical ion exchange application, zeolite samples from the deposit to be used should be thoroughly examined for its exploitation potential. This is due to cation exchange capacity of the zeolite distinctly dependent on its original cationic composition: not all the cationic sites in the zeolite structure are available for cation exchange; removal efficiency of ions from water solution increases with higher portion of the main component of natural zeolite (Margeta et al., 2013). 


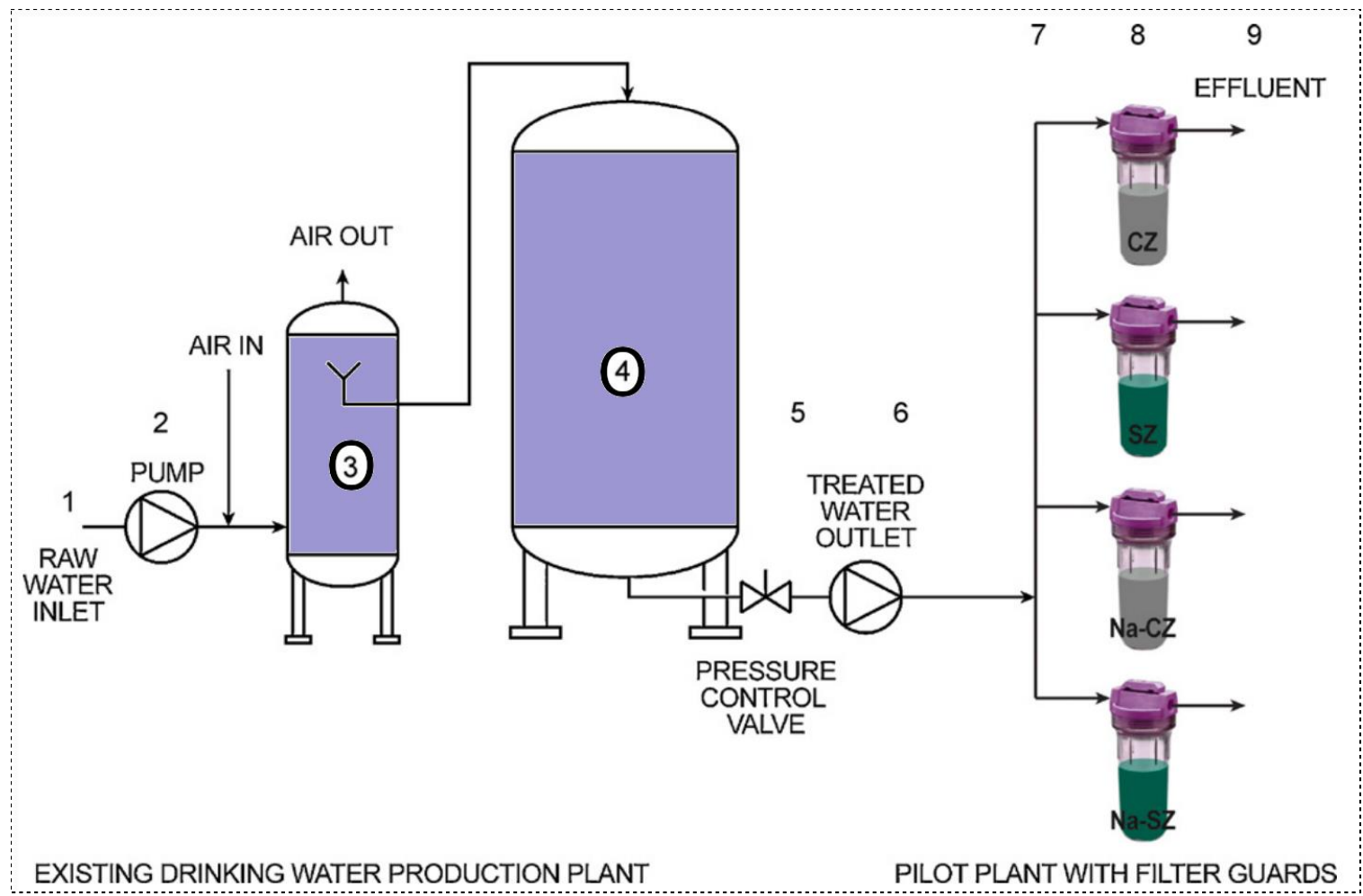

Figure 2. Scheme of drinking water production plant (1-5) and pilot plant "filter guards" (6-9): 1 - raw groundwater influent; 2 - pump; 3 - aeration tank; 4- filtration tank; 5- effluent VGW; 6-pump; 7-VGW influent; 8 - "filter guards" vessels filled with zeolite samples and 9 - effluent water (Šiljeg et al., 2010).

\section{ZEOLITE DEPOSITS AND TUFF QUALITY IN SERBIA}

The most important deposits of zeolite tuffs are: Zlatokop (Vranje Basin), Igroš (Kopaonik), Beočin (Fruška Gora), Toponica and Slanci (Danube Key near Belgrade) and Jastrebac mountain (near Kruševac) (Krizak et al., 2014; Kasic et al, 2017). The geological estimate of the available amount of zeolite in the deposits on solely Jastrebac mountain amount to 2,200,000 t of ore, while Zlatokop deposits amount to 550,000 t (Krizak et al., 2014). The zeolite tuffs themselves are mostly HEU type (Ca-clinoptilolite and Ca-heulandite), mostly present in the form of small needle-like to plate crystals measuring 0.1 to $100 \mu \mathrm{m}$. The zeolite tuff of the Zlatokop deposit is defined as Ca-clinoptilolite, while the zeolite tuffs of the Toponica, Beočin, Slanci and Igroš deposits are defined as Ca-heulandite (Kasic et al., 2017). Investigations have shown that zeolite tuff from the Zlatokop mine in the vicinity of Vranjska Banja contains $72 \%$ by weight of clinoptilolite, while feldspar (15\%) and quartz (13\%) are accompanying minerals (Stefanović et al., 2007). The cation exchange capacities of zeolite tuffs were found to have values from 96 to $166 \mathrm{meq} / 100 \mathrm{~g}$, and the external capacities range from 8.0 to $10.5 \mathrm{meq} / 100 \mathrm{~g}$ (Kasic et al., 2017). Based on detailed mineralogical, crystallochemical, thermal and X-ray examinations, various researchers have established that it is overall a raw material of high quality, relatively high concentration of zeolite in the ore and thus suitable for further application in various fields, including adsorption and ion exchange processes (Krizak et al., 2014, Kasic et al., 2017; Stefanović et al., 2007; Sekulić et al., 2013). Moreover, Margeta et al. (2013) provided a comparison of clinoptilolite from Serbia and from several countries in the vicinity. The comparison was based on different cation uptake potential of natural clinoptilolite. According to these findings, it can be concluded that clinoptilolite from Serbia mostly has greater use potential than clinoptilolite from other countries, leading to the question of its exploitation and current state of the zeolite industry in Serbia.

\section{ZEOLITE DEMAND, CURRENT EXPLOITATION AND INDUSTRIAL PRODUCTION}

After finding the value of aflatoxins in milk outside the permitted limits a few years ago, Serbian Ministry of Agriculture gave a suggestion to start using zeolites in animal nutrition in order to eliminate aflatoxins and other mycotoxins from animal feed. Since then, a large invasion of zeolite products has begun, both for livestock and field production. Moreover, a whole range of products for human use have appeared as well, which has absolutely no 
foundation or justification in science. However, this use of zeolite was not accompanied by adequate legislation, so the law still does not regulate the trade and use of zeolite and other non-metallic raw materials. Serbia currently uses between 7,000 and 10,000 tons of zeolite per annum (Krizak et al., 2014). Still, despite the fact that Serbian zeolite deposits are measured in millions of tons, almost all of the current demand comes from imports. On account of inadequate legislation, it is currently imported as "artistic stone", as "building stone", road aggregate, etc. Nevertheless, based on these, and the findings from the previous heading, it can safely be concluded that even if water treatment systems began using zeolites on a large scale, domestic deposits would be sufficient to satisfy all of the domestic demand. Moreover, Still, over the past decade, several companies such as "I-Zeolit", "Contractor Itd." and "Zeo kop" have made efforts in attempt to begin exploiting these deposits. The availability and distribution of zeolite ore in Serbia allows mining to be performed by universal mining machine with loading of ore in the truck. Excavation, in general, can be performed on benches of $3 \mathrm{~m}$ or even less depending on the quality of the zeolite in the layer (Krizak et al., 2014). This is basically a simple and efficient procedure. A concrete investment in the opening of the Zeolite natural mineral mine for a short period is said to be economically viable around two years, and for a longer period, from such profitability it is possible to upgrade products of the highest degree of processing, as well as the development of other branches of economic activity based on natural minerals. Furthermore, efforts to develop small and micro enterprises in an industry where local demand for locally produced raw materials is secure are highly desirable, especially in these economically turbulent and unsecure times, which proved evident during the COVID-19 pandemic (llić-Kosanović et al., 2020). Unfortunately, there is still no significant progress in this industry. Currently, the only exploited zeolite deposit in Serbia is Igroš Vidojevići near Brus, by the company "Zeo kop". Although ground zeolite can be used as an adsorbent with better characteristics compared to sand or charcoal, in order to be efficiently used in water purification columns as ion-exchanger, it needs to be modified and industrially processed into specific granulated form, for which Serbia currently does not have the industrial capacity. At the same time, neighboring Bosnia and Herzegovina already has working zeolite factory, near the border with Serbia. More precisely, 'Detergent zeolite production plant "Alusil" - Zvornik' and 'Granulated zeolite production plant "Alusil" Zvornik' which rests on the dryer of the detergent zeolite factory to minimize transportation costs (Stan- kovic \& Pezo, 2003; Stankovic \& Pezo, 2003a). The relative proximity to such a foreign plant, along the border with Serbia, is a favorable factor because it would enable the exploitation of a larger amount of granulated zeolite in the transition period, until domestic demand grows to a level that would be interesting to potential investors in domestic granulated zeolite production. However, in order to use Zeolite processed in Alusil, adequate laws and bylaws must be passed beforehand so that such import and possibly export of raw zeolite from Serbia would be possible. Finally, from this perspective, the use of zeolites in water purification systems seems to be a technology that does not carry major caveats with it, unlike some other "green" technologies that are questionable (Latinović et al., 2020; Latinović, 2019). In addition to drinking and waste water treatment, this mineral would also find application in the production of various products intended for foreign markets, which were not the subject of this paper.

\section{CONCLUSION}

Based on numerous studies, clinoptilolite was proven as a candidate that had a great potential as adsorbent and cation pollutant immobilizer in water treatment. In order to be successfully applied, pollutant immobilizers should be available in sufficient quantities, efficient and economically viable. All these requirements can be met with domestic zeolite deposits, but thorough legislation and extensive infrastructure have to be developed prior to its exploitation on a larger scale. Serbia has a huge natural potential in domestic zeolite deposits with the quality of zeolite tuff among the highest in the world. The use of zeolite as an adsorbent / ion-exchanger, i.e., immobilizer of water pollutants would additionally stimulate its consumption, increase the local demand and contribute to the development of the entire chain of companies. Furthermore, by strengthening this industry and increasing the supply, the price of zeolite is expected to decrease, which would have a positive impact on agriculture, where the largest quantities of this mineral are currently consumed, mostly from imports. Nevertheless, the conditio sine qua non is the determination of the state to solve the problem of pollution and balance between instantaneous economic expansion and preservation of the environment. Finally, the major issues in this area are not the technological parameters in the efficiency of removing certain pollutants from the water by zeolites, but lack of funding, previous inertia of the state in combating this problem, lack of water treatment plants and in the first place, inefficient system of fining the major pollution generators. The state must understand that this is a problem of vital importance 
for its inhabitants and start making major efforts in this direction, regardless of whether zeolite will be used in large scale water purification or not.

\section{REFERENCES}

[1] Bekkum, V. H., Flanigen, E.M., Jacobs, P.A., \& Jansen, J.C. (1991). Introduction to Zeolite Science and Practice, 2nd. Revised Edn., Elsevier, Amsterdam.

[2] Blanchard, G., Maunaye, M., \& Martin, G. (1984). Removal of heavy metals from waters by means of natural zeolites. Water Research, 18(12), 1501-1507.

[3] Damnjanović, A. (2020). Ekološki porezi u funkciji zaštite životne sredine Republike Srbije. Ecologica, 27(98), 299-305.

[4] Doula, M. K. (2009). Simultaneous removal of $\mathrm{Cu}$, $\mathrm{Mn}$ and $\mathrm{Zn}$ from drinking water with the use of clinoptilolite and its Fe-modified form. Water Research, 43(15), 3659-3672.

[5] Du, Q., Liu, S., Cao, Z., \& Wang, Y. (2005). Ammonia removal from aqueous solution using natural Chinese clinoptilolite. Separation and Purification Technology, 44(3), 229-234.

[6] Erdem, E., Karapinar, N., \& Donat, R. (2004). The removal of heavy metal cations by natural zeolites. Journal of Colloid and Interface Science, 280(2), 309-314.

[7] Fosso-Kankeu, E., Mulaba-Bafubiandi, A., Modipe, J.T. \& Maroga, S.E. (2013). Regeneration and reuse of clinoptilolite for recovery of copper and cobalt from aqueous solutions. International Conference on Chemical, Industrial, Environmental, Mining and Metallurgical Engineering (ICCIEMME 2013) At: Johannesburg (South Africa).

[8] Garaplija, A. (2020). Integrisano upravljanje otpadom u skladu sa "ISO 31000" standardima za upravljanje rizicima i "Nacionalnom strategijom održivog razvoja" u Republici Srbiji. Serbian Journal of Engineering Management, 5(2), 50-59.

[9] Gedik, K., \& Imamoglu, I. (2008). Removal of cadmium from aqueous solutions using clinoptilolite: Influence of pretreatment and regeneration. Journal of Hazardous Materials, 155(1-2), 385-392.

[10] Gorimbo, J. (2011). Effect of the homoionic form of clinoptilolite on $\mathrm{Ni}^{2}$ adsorption isotherms: $\mathrm{A}$ thermodynamic study (Master's thesis). Faculty of Engineering and the Built Environment, University of the Witwatersrand. Johannesburg.

[11] llić, M., \& Nikolić, M. (2016). Drivers for development of circular economy - A case study of Serbia. Habitat International, 56, 191-200.
[12] llić-Kosanović, T., Tomašević, V., \& Ilić, D. (2020). Mikro i mala preduzeća i očuvanje ljudskih resursa u uslovima pandemije. Serbian Journal of Engineering Management, 5(2), 77-85.

[13] Inglezakis, V. J., Doula, M. K., Aggelatou, V., \& Zorpas, A. A. (2010). Removal of iron and manganese from underground water by use of natural minerals in batch mode treatment. Desalination and Water Treatment, 18(1-3).

[14] Jovanović, Đ., Bajac, M., Radović, D., Matavulj, M., \& Antonović, D. (2013). Attitude towards the environment in the context of the strategic development of system of values in Serbia. Ecologica, 20(71), 375-380.

[15] Jovanović, Đ., Stokić, D., Matavulj, M., \& Igić, S. (2013). Strategic importance of development of ISO 14000 standards in Republic of Serbia. Ecologica, 20 (72), 637-643.

[16] Jovanović, L., \& Ermakov, V. (2020). Značaj selena i cinka u prevenciji i lečenju virusnih oboljenja. Ecologica, 27(99), 357-365.

[17] Jovanović, M. B. (2016). Uklanjanje jona metala iz vodenih rastvora korišćenjem zeolita: mehanizam, kinetika i primena u fluidizovanom sloju (dissertation, in Serbian). University of Belgrade. Faculty of Technology and Metallurgy. Belgrade.

[18] Karadag, D., Koc, Y., Turan, M., \& Armagan, B. (2006). Removal of ammonium ion from aqueous solution using natural Turkish clinoptilolite. Journal of Hazardous Materials, 136(3), 604-609.

[19] Kasic, V., Simic, V., Zivotic, D., RadosavljevicMihajlovic, A., \& Stojanovic, J. (2017). Mineralogy and crystallochemical characteristics of HEUtype minerals from zeolitic tuff deposits of Serbia. Hemijska Industrija, 71(1), 49-60.

[20] Korać, S., Mićin, M., \& Čupić, D. (2019). Održivi razvoj - prelazak na zelenu ekonomiju - bezbednosne implikacije. Serbian Journal of Engineering Management, 4(1), 22-34.

[21] Krizak, D., Maksimovic, M., \& Vojnovic, D. (2014). 'Jablanica 1': Prospective zeolite deposit. Tehnika, 69(2), 225-230.

[22] Latinović, L. (2019). Proizvodnja i obavezna upotreba biodizela u Srbiji sa aspekta ekonomskog uticaja na stanovništvo. Serbian Journal of Engineering Management, 4(2), 29-38.

[23] Latinović, L. (2018). Nova paradigma u recikliranju - inovativni pristup recikliranju plastičnog otpada u Srbiji. Serbian Journal of Engineering Management, 3(2), 1-12.

[24] Latinović, L., Jovanović, Đ. (2019). Application of the "Smart City concept" through efficient recyclable waste collection. Ecologica, 26(95), 364370. 
[25] Latinović, L., Stojić, N., \& Latinović, J. (2020). Važni faktori pri oživljavanju industrije biodizela u Srbiji - prilika ili zamka? Serbian Journal of Engineering Management, 5(2), 1-19.

[26] Li, Z., Jean, J.-S., Jiang, W.-T., Chang, P.-H., Chen, C.-J., \& Liao, L. (2011). Removal of arsenic from water using Fe-exchanged natural zeolite. Journal of Hazardous Materials, 187(1-3), 318323.

[27] Margeta K., Zabukovec N., Siljeg M., \& Farkas A. (2013). Natural Zeolites in Water Treatment How Effective is Their Use. In: Water Treatment, Chapter 5, Publ.: in Tech, doi:10.5772/50738

[28] Rajic, N., Stojakovic, D., Jovanovic, M., Logar, N. Z., Mazaj, M., \& Kaucic, V. (2010). Removal of nickel(II) ions from aqueous solutions using the natural clinoptilolite and preparation of nano-NiO on the exhausted clinoptilolite. Applied Surface Science, 257(5), 1524-1532.

[29] Sekulic, Z., Dakovic, A., Kragovic, M., Markovic, M., Ivosevic, B., \& Kolonja, B. (2013). Quality of zeolit from Vranjska banja deposit according to size classes. Chemical Industry / Hemijska Industrija, 67(4), 663-669.

[30] SEPA. (2019). Report on the state of the environment in the Republic of Serbia for 2018 (In Serbian). Serbian Environmental Protection Agency. Ministry for Environmental protection. Available at: http://www.sepa.gov.rs/download/ Izvestaj2018.pdf. Accessed: August 18, 2020.
[31] Šiljeg, M., Foglar, L., \& Kukučka, M. (2010). The ground water ammonium sorption onto Croatian and Serbian clinoptilolite. Journal of Hazardous Materials, 178(1-3), 572-577.

[32] Stankovic, M., Pezo, L. (2003). Granulated zeolite plant "Alusil", Zvornik. Hemijska Industrija, 57(2), 51-53.

[33] Stankovic, M., Pezo, L. (2003a). Detergent zeolite complex "Alusil", Zvornik. Hemijska Industrija, 57(2), 47-50.

[34] Stefanović C. Š., Zabukovec L. N., Margeta K., Novak T. N., Arčon I., Maver K., Kovač J., Kaučič V. (2007). Structural investigation of $\mathrm{Zn}^{2+}$ sorption on clinoptilolite tuff from the Vranjska Banja deposit in Serbia, Micropor. Mesopor. Mat. 105, 251-259.

[35] Tarasevich, Y. I., Goncharuk, V. V., Polyakov, V. E., Krysenko, D. A., Ivanova, Z. G., Aksenenko, E. V., \& Tryfonova, M. Y. (2012). Efficient technology for the removal of iron and manganese ions from artesian water using clinoptilolite. Journal of Industrial and Engineering Chemistry, 18(4).

[36] Turanjanin, D., Cvetanović, S., \& Popović, J. (2020). Global environmental quality problems in economic development policy. Ecologica, 27 (100), 714-722.

[37] Zamzow, M. J., Eichbaum, B. R., Sandgren, K. R., \& Shanks, D. E. (1990). Removal of Heavy Metals and Other Cations from Wastewater Using Zeolites. Separation Science and Technology, 25(13-15), 1555-1569. 